\title{
Predicting plant community response to picloram
}

\author{
SUSAN A. KEDZIE-WEBB, ROGER L. SHELEY, AND JOHN J. BORKOWSKI
}

Authors are Graduate Research Assistant and Associate Professor, Department of Land Resources Environmental Sciences, and Associate Professor, Department of Mathematical Sciences, Montana State University, Bozeman, Mont. 59717.

Abstract

Effective rangeland weed programs require the ability to predict plant community responses to management. Our objective was to develop regression equations to predict the plant community after control with picloram using the pre-treatment plant community. Five transects were established from dense spotted knapweed (Centaurea maculosa Lam.) in the center of each patch to an area of low or no spotted knapweed occurrence on the outside of the patch. Transects ended in areas dominated by Idaho fescue (Festuca idahoensis Elmer). Twenty permanent plots $(20 \mathrm{x}$ $50 \mathrm{~cm}$, spacing along the transect ranged from $1 / 2$ to $2 \mathrm{~m}$ ) were placed along this gradient. Pre-treatment density and cover of all species were sampled in each plot. Biomass of all species was harvested in plots adjacent to the transect. Picloram (4-amino-3,5,6trichloropicolinic acid) was applied along each transect at a rate of $0.28 \mathrm{~kg}$ a.i. $\mathrm{ha}^{-1}$ in October 1996 to each plot. Density, cover, and biomass of all species were re-sampled in August 1998. Regression models were fit using perennial grasses, Idaho fescue, forbs, species richness, and species diversity after treatment as predicted variables. All predicted variables were indigenous species. Regressor variables used were site, transect, and spotted knapweed, a spotted knapweed quadratic component, indigenous perennial grasses, Idaho fescue, indigenous forbs, species richness, and species diversity sampled in the first year (1996) prior to treatment. The best predictive models for assessing post-management indigenous perennial grass, Idaho fescue, and species richness were based on density. The best models predicting postmanagement forbs and species diversity were based on cover and biomass, respectively. In 4 out of the 5 models, for a given postmanagement parameter, an important predictor in the model was its pre-management regressor variable. Additionally, premanagement spotted knapweed was a relatively unimportant predictor in most models. The model predicting species diversity based on density (pre-treatment) predicted an increase in species diversity 2 years after management. This study indicated that it may be feasible to use pre-management plant community data to predict post-management plant community response for spotted knapweed-infested rangeland using picloram.

Key Words: Spotted knapweed, predicting plant response, integrated weed management, optimizing herbicide use

Over the past century, loss of indigenous rangeland communities in North America has been related to the invasion of aggressive non-indigenous species (Kedzie-Webb 1999). Ecological impacts attributed to non-indigenous invasions include the dis-

\section{Resumen}

Los programas efectivos de control de malezas en los pastizales requieren de la habilidad para predecir las respuestas de la comunidad vegetal al manejo. Nuestro objetivo fue desarrollar ecuaciones de regresión para predecir la comunidad vegetal después del control con picloram usandolo como pre-tratamiento de la comunidad vegetal. Se establecieron 5 transectos desde el centro de cada parche, en donde "Spotted knapweed" (Centaurea maculosa Lam.) tenía una alta densidad, hasta un área fuera del parche, donde la densidad de "Spotted knapweed" era baja o no estaba presente. Los transecto terminaron en áreas dominadas por "Idaho fescue" (Festuca idahoensis Elmer). Se colocaron 25 parcelas permanentes de $(20 \times 50 \mathrm{~cm}$, el espaciamiento entre parcelas a lo largo fue de $2 \mathrm{~m}$ ) a lo largo de este gradiente. La densidad y cobertura de todas las especies se muestreó en cada parcela antes de aplicar los tratamientos. Se cosechó la biomasa de todas las especies en parcelas adyacentes al transecto. En Octubre de 1996, el Picloram (4-amino-3,5,6ácido tricloropicolinico) se aplicó en cada parcela a lo largo del transecto a una dosis de $0.28 \mathrm{~kg}$ i.a. ha $^{-1}$. La densidad, cobertura y biomasa de todas las especies se muestrearon nuevamente en Agosto de 1998. Los modelos de regresión se ajustaron utilizando como variables predichas los zacates perennes, el " Idaho fescue", las hierbas, la riqueza de especies y la diversidad de especies después del tratamiento. Todas la variables predichas fueron especies nativas. Las variables regresoras utilizadas fueron: sitio, transecto y Spotted knapweed", un componente cuadrático de "Spotted knapweed, zacates perennes nativos, "Idaho fescue", hierbas nativas, riqueza de especies y la diversidad de especies muestreada en el primer año (1996) antes del tratamiento. Los mejores modelos predictivos para evaluar el manejo post-tratamiento de zacates perennes nativos, "Idaho fescue" y la riqueza de especies fueron basados en la densidad. Los mejores modelos para predecir el manejo post-tratamiento de las hierbas y la diversidad de especies se basaron en cobertura y biomasa respectivamente. En 4 de los 5 modelos, para un parámetro post-tratamiento dado, un predictor importante en el modelo fue su variable regresora de pre- tratamiento. Adicionalmente, el manejo pre-tratamiento del " Spotted knapweed" fue un predictor relativamente sin importancia en la mayoría de los modelos. El modelo para predecir la diversidad de especies basado en la densidad (pre-tratamiento) predijo un incremento en la diversidad de especies 2 años después del tratamiento. Este estudio indica que puede ser factible el uso de los datos de la comunidad vegetal pre-tratamiento para predecir la respuesta de la comunidad vegetal después del tratamiento en pastizales infestados de "Spotted knapweed" tratados con Picloram. 
placement of indigenous plant species, declines in biodiversity, and degradation of ecosystem function (Vitousek 1986, Randall 1996). In the western United States, saltcedar (Tamarix spp.) (Brotherson and Field 1987), leafy spurge (Euphorbia esula L.) (Belcher and Wilson 1989), downy brome (Bromus tectorum L.) (Mack 1981, Whisenant 1990), spotted knapweed (Centaurea maculosa Lam.), and others have been documented to alter ecosystem function (Tyser and Key 1988). Ecosystem processes threatened by invasive species include primary and secondary productivity, decomposition, nutrient cycles (accumulation or loss), soil development and fertility, and hydrologic cycles (Vitousek and Hooper 1993). In a single, cursory study, Lacey et al. (1989) suggested that surface run-off and sediment yield increased on spotted knapweed-dominated sites under simulated rain events. Spotted knapweed negatively impacts wildlife through forage production loss, habitat modification, or by altering animal-plant interactions (Thompson 1996). Invasion by spotted knapweed into western Montana has reduced winter forage for elk resulting in an estimated loss of 220 elk annually (Spoon et al. 1983). A major economic impact of spotted knapweed invasion is the loss of livestock forage production (Bucher 1984).

Rangeland managers are searching for useful models on which to base their decisions (Archer 1989, Laycock 1991, Schlatterer 1989). The more accurate the predictions, the greater success in developing integrated weed management systems (Schreiber 1982). Coupled with the concept of thresholds, predicting plant community response to regulation may enhance management by providing managers with the information necessary to make thoughtful decisions (Griffith and Lacey 1991).

The overall objective of this study was to determine the potential to predict the post-treatment plant community after a herbicide treatment of spotted knapweed based on the pre-treatment plant community. Specific objectives were to: 1) develop models that predict the post-picloramtreatment plant community composition based on the pre-treatment plant community after a picloram treatment; 2) initiate development of a method to use easily collected field data to predict pre- and postmanagement biomass; and 3) introduce a method to use predictions to enhance weed management decisions. Since cover data is one of the easiest parameters to collect, using cover to predict biomass may be the most practical and efficient model for decision-making. Although this study was conducted using an herbicide, this method could be used in a similar fashion to predict post-treatment plant community response based on the pre-treatment plant community and application of other management techniques (e.g., grazing, fire, biocontrol, etc.). This research is necessary to improve decision-making abilities and management strategies.

\section{Materials and Methods}

This study was conducted on 2 sites from 1996 through 1998 within a Idaho fescue-bluebunch wheatgrass (Festuca idahoensis-Agropyron spicatum) habitat type (Mueggler and Stewart 1980). Site 1 was located in Story Hills $\left(45^{\circ} 42^{\prime} \mathrm{N}, 111^{\circ}\right.$ $01^{\prime} \mathrm{W}$ ), four $\mathrm{km}$ northeast of Bozeman, Mont. Elevation at this site is $1,478 \mathrm{~m}$. Average annual precipitation is $432 \mathrm{~mm}$. Soil is a clayey-skeletal, mixed Typic Argiborolls. Site 2 was located at Beartrap Canyon, about $45 \mathrm{~km}$ east of Norris, Mont. ( $\left.45^{\circ} 36^{\prime} \mathrm{N}, 111^{\circ} 34^{\prime} \mathrm{W}\right)$. Elevation is $788 \mathrm{~m}$ with an average annual precipitation of $305 \mathrm{~mm}$. Soil at Site 2 is classified as a loamy-skeletal, mixed Aridic Argiborolls.

Five transects, each $20 \mathrm{~m}$ long, were established at both sites. Transects radiated from dense spotted knapweed in the center of each patch to an area of low or no spotted knapweed occurrence on the outside of the patch. At each site, all transects radiated from the center of the same patch. The plant community at each transect origin was dominated by spotted knapweed with few or no residual indigenous species growing in association. Transects ended in areas dominated by Idaho fescue (Festuca idahoensis Elmer) with a diverse group of associated species. Twenty permanent plots $(20 \times 50 \mathrm{~cm}$, spacing along the transect ranged from 2 to $2 \mathrm{~m}$ ) were placed along this gradient of spotted knapweed cover from 0 to $100 \%$ (about every 5\%). Pre-treatment density (juveniles plus adults) and cover of all species were sampled in each plot. Picloram (4-amino-3,5,6-trichloropicolinic acid) was applied along each transect in a $2 \mathrm{~m}$ swath at a rate of $0.28 \mathrm{~kg}$ a.i. ha ${ }^{-1}$ in October of 1996 to each plot. Density (juveniles plus adults) and cover of all species were re-sampled in August 1998.

Thirty temporary plots $(20 \times 50 \mathrm{~cm})$ were also established along the spotted knapweed gradient to sample biomass and soil at each site. Biomass was sampled for all species by clipping plants to groundlevel at peak standing crop in August 1996 and 1998. Samples were dried at $60^{\circ} \mathrm{C}$ to a constant weight and weighed. Soil samples were collected along the transect to determine whether the spotted knapweed gradient was related to differences in soil nutrients. Soil samples were tested for available nitrogen, phosphorous, and potassium using a standardized extraction process (Page and Klute 1982). There were no differences in available soil nutrients, therefore, the data are not presented.

\section{Data Analysis}

Data were compiled into tables showing the number of transects in which individual species were present both before and after the picloram treatment (maximum of 5). Plant density, cover, and biomass data were analyzed using a multi-step process. Covariance analysis was conducted to test for sample independence within transects. Analysis indicated independence among all plots, therefore, a step-down linear regression procedure was used to identify the best model (Neter et al. 1985). A combination of P-value, model simplicity, and $\mathrm{R}^{2}$ values was used to identify the best model for each step-down procedure. Scatter-plots of the residuals versus the standardized predicted values were used to evaluate heterogeneity of variance for each model. Data transformations were conducted where necessary on predicted and/or regressor variables using squareroot transformations. Inverse, quadratic, and $\log$ transformations were tested, but did not improve the models. Collinearity was evaluated using a SAS tolerance procedure to test for relatedness of predictors (SAS 1990). Collinearity was not a problem in this analysis.

Regression models were fit using density, cover, and biomass after treatment (1998) as predicted variables that include perennial grasses, Idaho fescue, forbs, species richness, and species diversity. All predicted variables were indigenous species. Regressor variables used were site, transect, and density, cover, and biomass of spotted knapweed, a spotted knapweed quadratic component, indigenous perennial grasses, Idaho fescue, indigenous forbs, species richness, and species diversity sampled in the first year (1996) prior to treatment.

Regression models were also fit using density, cover, and biomass of brome species post-treatment as predicted variables. In these models, regressor variables were density, cover, and biomass of pretreatment brome species, a brome quadrat- 
ic component, spotted knapweed, and a spotted knapweed quadratic component.

Additionally, regression models were fit to predict production from cover. The predicted variables include: post-treatment indigenous perennial grass, Idaho fescue, forbs, and brome species biomass. Regressor variables used were pre-treatment indigenous perennial grass, Idaho fescue, indigenous forbs, brome species cover, and their respective quadratic components.

All models presented were significant at $\mathrm{P} \leq 0.05$. The effects of transects were averaged across sites when significant. Coefficient means and standard deviations for transects are presented. These regression models do not imply causality. Diversity measurements were estimated using Shannon-Weaver's diversity index (Shannon and Weaver 1949).

\section{Results}

\section{Presence and Distribution}

Nine indigenous grasses, 2 non-indigenous grasses, 9 indigenous forbs, and 3 non-indigenous forbs were present at Site 1. Of the indigenous grasses, bluebunch wheatgrass [Agropyron spicatum (Pursh)
Scribn. \& Smith] was found in 3 or more transects, and western wheatgrass (Agropyron smithii Rydb.) was present in at least 1 transect along the gradient. Idaho fescue was present in all transects except at 85 and $90 \%$ pre-treatment spotted knapweed. All other indigenous grasses were limited in presence after $50 \%$ pre-treatment spotted knapweed. Japanese brome (Bromus japonicus Thunb.) was present along the entire transect. Kentucky bluegrass (Poa pratensis L.) was limited in presence below $30 \%$ pre-treatment spotted knapweed. The most abundant indigenous forbs included hairy goldenaster [Chrysopsis villosa (Pursh) Nutt.], blazingstar (Liatris punctata Hook.) and sagewort cudweed (Artemisia ludoviciana). Posttreatment bastard toadflax [Comandra umbellata (L). Nutt.] was the most abundant non-indigenous forb present at Site 1.

Seven indigenous grasses, 3 non-indigenous grasses, 5 indigenous forbs and 2 nonindigenous forbs were present at Site 2 . Blue grama [Bouteloua gracilis (H. B. K.) Lag.] was present along the entire gradient. Idaho fescue was found at all pre-treatment spotted knapweed levels except 70 and $100 \%$. Prairie sandreed (Calamovilfa longi- folia Hook.) and needle-and-thread grass (Stipa comata Trin. \& Rupr.) were well represented along the transect except above $60 \%$ spotted knapweed. The most abundant forb based on presence in number of transects was the non-indigenous Berteroa spp.

\section{Density}

Regression models were generated to predict the plant density 2 years after picloram treatment (predicted variables) based on the density of plants sampled prior to treatment (regressor variables) (Table 1). Site was significant when predicting Idaho fescue and forb density, as well as species richness based on density. Estimated effects of site were $-8.8,-5.0$, and 19.7 for species richness, forbs, and Idaho fescue density, respectively.

For each 1 unit increase in pre-treatment indigenous perennial grass density, predicted post-treatment indigenous perennial grass density increased by about 9.2 tillers $\mathrm{m}^{-2}$ (Table 1). For each 1 unit increase in spotted knapweed density, predicted indigenous perennial grass density decreased by 0.1 tillers $\mathrm{m}^{-2}$ at Site 1 . At Site 2 , for each 1 unit increase in spotted knapweed density, predicted indigenous perenni-

Table 1. Regression models predicting post-treatment indigenous species based on pre-treatment density (plants $\mathbf{m}^{-2}$ ) of regressor variables. Empty cells represent non-significant regressor variables.

\begin{tabular}{|c|c|c|c|c|c|c|c|c|c|c|c|c|}
\hline & & & & Regressor & variables & & & & & & & \\
\hline Site & $\begin{array}{l}\text { Predicted } \\
\text { variables }\end{array}$ & Intercept & Site & $\begin{array}{c}\text { Transect } \\
\text { (1) }\end{array}$ & $\begin{array}{c}\text { Perennial } \\
\text { grass } \\
(0 \text { to } 7,280)\end{array}$ & $\begin{array}{c}\text { Idaho } \\
\text { fescue } \\
\text { (0 to } 3,970)\end{array}$ & $\begin{array}{c}\text { Forbs } \\
(0 \text { to } 550)\end{array}$ & $\begin{array}{l}\text { Species } \\
\text { richness } \\
(0 \text { to } 8)\end{array}$ & $\begin{array}{c}\text { Species } \\
\text { diversity } \\
(0 \text { to } 2.26)^{\prime}\end{array}$ & $\begin{array}{c}\text { Spotted } \\
\text { knapweed } \\
(0 \text { to } 1,170)\end{array}$ & $\begin{array}{c}\text { Spotted } \\
\text { knapweed }^{2} \\
(0 \text { to } 313,290)\end{array}$ & $\mathrm{R}^{2}$ \\
\hline 1 & $\begin{array}{l}\text { Perennial } \\
\text { grass }^{2}\end{array}$ & 19.2 & & $\begin{array}{c}5.5^{3} \\
(6.8)\end{array}$ & 9.2 & & & & & -0.1 & & 0.51 \\
\hline 2 & $\begin{array}{l}\text { Perennial } \\
\text { grass }\end{array}$ & 19.2 & & $\begin{array}{c}5.5 \\
(6.8)\end{array}$ & 9.2 & & & & & 0.4 & & 0.51 \\
\hline 1 & $\begin{array}{l}\text { Idaho } \\
\text { fescue }\end{array}$ & -17.4 & 0.00 & & & 9.5 & & & 14.1 & & & 0.69 \\
\hline 2 & $\begin{array}{l}\text { Idaho } \\
\text { fescue }\end{array}$ & -17.4 & 19.7 & -2.8 & & 9.5 & & 14.1 & & & & 0.69 \\
\hline 1 & Forbs & 7.2 & 0.00 & (2.8) & -0.68 & & & 2.3 & & & & 0.34 \\
\hline 2 & Forbs & 7.2 & -5.0 & $\begin{array}{l}-2.8 \\
(2.8)\end{array}$ & -0.68 & & & 2.3 & & & & 0.34 \\
\hline 1 & $\begin{array}{l}\text { Species } \\
\text { richness }\end{array}$ & 17.8 & 0.00 & & 1.5 & & & 4.4 & & & 0.002 & 0.46 \\
\hline 2 & $\begin{array}{l}\text { Species } \\
\text { richess }\end{array}$ & 17.8 & -8.8 & & 1.5 & & & 4.4 & & & -0.004 & 0.46 \\
\hline 1 & Diversity & 3.3 & & $\begin{array}{c}-1.0 \\
(1.1)\end{array}$ & 0.8 & & & & 1.7 & & & 0.30 \\
\hline 2 & Diversity & 3.3 & & $\begin{array}{l}-1.0 \\
(1.1)\end{array}$ & 0.8 & & & & 1.7 & & & 0.30 \\
\hline Pos: & $\begin{array}{r}\text { ble range of va } \\
\text { del predicting } \\
\text { Site } 1 ; y=1 \\
\text { treatment.an } \\
\text { Site } 2 ; y=1 \\
\text { of CEMA at } \\
\text { s represent the }\end{array}$ & $\begin{array}{l}\text { s for each } p \\
\text { st-treatment } \\
\left(\mathrm{B}_{0}\right)+5.5(\mathrm{I} \\
3_{3} \text { is the den } \\
\left(\mathrm{B}_{0}\right)+5.5(\mathrm{H} \\
\text { te } 2 \text {. }\end{array}$ & $\begin{array}{l}\text { arameter } \\
\text { IPG den } \\
1)+9.2(\mathrm{I} \\
\text { ity of C } \\
1)+9.2(\mathrm{I}\end{array}$ & $\begin{array}{l}\text { a m}^{-2} \text { basis. } \\
\text { based on } \mathrm{pr} \\
-0.10\left(\mathrm{~B}_{3}\right), \\
\mathrm{A} \text { at } \mathrm{Site} 1 . \\
+\left(0.40\left(\mathrm{~B}_{3}\right) \text {, }\right.\end{array}$ & $\begin{array}{l}\text { e-treatment dens } \\
\text { here } B_{0} \text { is the in } \\
\text { where } B_{0} \text { is the } i\end{array}$ & $\begin{array}{l}\text { ity of PIG and C } \\
\text { tercept, } B_{1} \text { is th } \\
\text { ntercept, } B_{1} \text { is tl }\end{array}$ & $\begin{array}{l}\mathrm{e} \text { average of } t \\
\text { he average of }\end{array}$ & $\begin{array}{l}\text { includes } \\
\text { sect, } B_{2} \text { is } \\
\text { nsect, } B_{2} \text { is }\end{array}$ & $\begin{array}{l}\text { e density of th } \\
\text { he density of th }\end{array}$ & $\begin{array}{l}\text { indigenous per } \\
\text { IPG prior to }\end{array}$ & $\begin{array}{l}\text { nnial grass prior to } \\
\text { eatment.and } B_{3} \text { is } t\end{array}$ & e density \\
\hline
\end{tabular}


Table 2. Regression models predicting post-treatment indigenous species based on pre-treatment cover of regressor variables. Empty cells represent non-significant regressor variables.

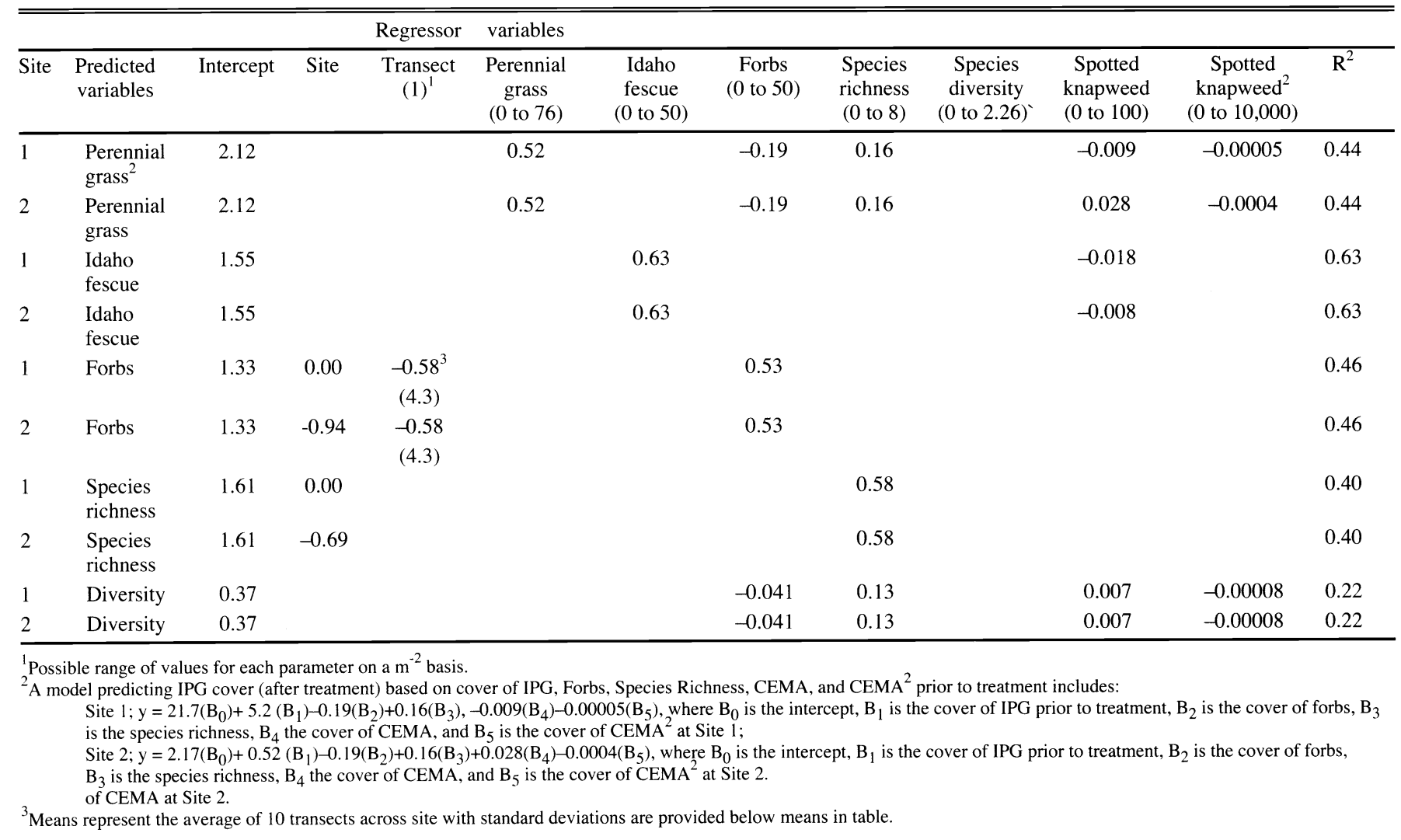

al grass density increased by 0.4 tillers $\mathrm{m}^{-2}$. Effect of transect was positively associated with indigenous perennial grass density.

In the model predicting Idaho fescue density, post-treatment Idaho fescue density was positively associated with pre-treatment Idaho fescue density and species diversity (Table 1). Specifically, each 1 unit increase in pre-treatment Idaho fescue density was associated with a 9.5 tillers $\mathrm{m}^{-2}$ increase in post-treatment Idaho fescue density. For each 1 unit increase in species diversity, Idaho fescue density increased by 14.1 tillers $\mathrm{m}^{-2}$.

In general, predicted post-treatment indigenous forb density was negatively related to pre-treatment indigenous perennial grass density and positively related to species richness (Table 1). For each 1 unit increase in indigenous perennial grass density, forb density decreased by 0.68 plants $\mathrm{m}^{-2}$. Each 1 unit increase in species richness was associated with a predicted 2.3 plants $\mathrm{m}^{-2}$ increase in forb density. Effect of transect was negatively associated with forb density.

For each 1 unit increase in indigenous perennial grass density, predicted species richness increased by about 1.5 plants $\mathrm{m}^{-2}$ at both sites (Table 1). For each 1 unit increase in pre-treatment species richness, predicted post-treatment species richness increased by 4.4 plants $\mathrm{m}^{-2}$ at both sites. The spotted knapweed quadratic component was associated with an increase in species richness by about 0.002 plants $\mathrm{m}^{-2}$ at Site 1 and a decrease of 0.004 plants $\mathrm{m}^{-2}$ at Site 2.

Predicted post-treatment species diversity was positively related to both pre-treatment indigenous perennial grass density and species diversity (Table 1). Each 1 unit increase in indigenous perennial grass density was associated with an increase in species diversity by 0.8 ShannonWeaver's diversity index units. For each 1 unit increase in pre-treatment species richness, post-treatment species diversity increased by 1.7 Shannon-Weaver's diversity index units. Effect of transect was negatively associated with species diversity at both sites.

\section{Cover}

Site was significant when predicting forb cover and species richness based on cover. The estimated effects of site were -0.94 and -0.69 for forbs and species richness, respectively (Table 2).

Predicted post-treatment indigenous perennial grass cover was positively related to indigenous perennial grass and species richness, but negatively related to forb cover at both sites (Table 2). Each 1\% increase in pre-treatment indigenous perennial grass cover was associated with a $52 \%$ increase in post-treatment indigenous perennial grass cover. For each $1 \%$ increase in forb cover, indigenous perennial grass cover decreased by $19 \%$. Each $1 \%$ increase in species richness based on cover was associated with a predicted increase in indigenous perennial grass cover by $16 \%$. For each $1 \%$ increase in spotted knapweed cover, indigenous perennial grass cover decreased by $0.9 \%$ at Site 1 and increased by $2.8 \%$ at Site 2 . Each $1 \%$ increase in the spotted knapweed quadratic component was associated with a decrease in indigenous perennial grass cover by 0.005 and $0.04 \%$ for Sites 1 and 2 , respectively.

In general, predicted post-treatment Idaho fescue cover was positively related to pre-treatment Idaho fescue cover (Table $2)$. Each $1 \%$ increase in pre-treatment Idaho fescue cover was associated with an increase in post-treatment Idaho fescue cover by $63 \%$. Each $1 \%$ increase in spotted knapweed cover was associated with a predicted decrease in Idaho fescue cover 
Table 3. Regression models predicting post-treatment indigenous species based on pre-treatment biomass (plants $\mathbf{m}^{-2}$ ) of regressor variables. Empty cells represent non-significant regressor variables.

\begin{tabular}{|c|c|c|c|c|c|c|c|c|c|c|c|c|}
\hline & & & & Regressor & variables & & & & & & & \\
\hline Site & $\begin{array}{l}\text { Predicted } \\
\text { variables }\end{array}$ & Intercept & Site & $\begin{array}{l}\text { Transect } \\
(1)^{1}\end{array}$ & $\begin{array}{l}\text { Perennial } \\
\text { grass } \\
(0 \text { to } 380)\end{array}$ & $\begin{array}{c}\text { Idaho } \\
\text { fescue } \\
\text { (0 to } 360)\end{array}$ & $\begin{array}{c}\text { Forbs } \\
(0 \text { to } 150)\end{array}$ & $\begin{array}{c}\text { Species } \\
\text { richness } \\
\text { (0 to 5) }\end{array}$ & $\begin{array}{c}\text { Species } \\
\text { diversity } \\
(0 \text { to } 2.26)^{\circ}\end{array}$ & $\begin{array}{c}\text { Spotted } \\
\text { knapweed } \\
(0 \text { to } 1,280)\end{array}$ & $\begin{array}{c}\text { Spotted } \\
\text { knapweed }^{2} \\
\text { (0 to } 163,840)\end{array}$ & $\mathrm{R}^{2}$ \\
\hline 2 & $\begin{array}{l}\text { Perennial } \\
\text { grass }\end{array}$ & 14.7 & & & & & 2.7 & & & 0.40 & -0.004 & 0.32 \\
\hline 2 & $\begin{array}{l}\text { Idaho } \\
\text { fescue }\end{array}$ & -1.2 & & & 5.4 & & & & & & & 0.39 \\
\hline 1 & Forbs & 3.2 & & $\begin{array}{r}-2.5^{3} \\
(7.5)\end{array}$ & & & -5.0 & 4.0 & & -0.18 & & 0.38 \\
\hline 2 & Forbs & 3.2 & & $\begin{array}{l}-2.5 \\
(7.5)\end{array}$ & & & -5.0 & 4.0 & & 0.02 & & 0.38 \\
\hline 1 & Diversity & 3.1 & & $\begin{array}{l}-3.6 \\
(3.9)\end{array}$ & 2.2 & & & & & 0.11 & -0.0015 & 0.52 \\
\hline 2 & Diversity & 3.1 & & $\begin{array}{l}-3.6 \\
(3.9)\end{array}$ & 2.2 & & & & & 0.24 & -0.0015 & 0.52 \\
\hline
\end{tabular}

${ }_{1}^{1}$ Possible range of values for each parameter on a $\mathrm{m}^{-2}$ basis

${ }^{2} \mathrm{~A}$ model predicting post-treatment IPG biomass based on biomass of Forbs, CEMA, and CEMA ${ }^{2}$ prior to treatment includes

Site $1 ; y=14.7\left(B_{0}\right)+2.7\left(B_{1}\right)-0.07\left(B_{2}\right)+0.0007\left(B_{3}\right)$, where $B_{0}$ is the intercept, $B_{1}$ is the biomass of forbs prior to treatment, $B_{2}$ is the biomass of $C E M A, B_{3}$ is the biomass of CEMA ${ }^{2}$ at Site 1 ;

Site $2 ; y=14.7\left(B_{0}\right)+2.7\left(B_{1}\right)+0.38\left(B_{2}\right)-00004\left(B_{3}\right)$, where $B_{0}$ is the intercept, $B_{1}$ is the biomass of forbs prior to treatment, $B_{2}$ is the biomass of $C E M A B_{3}$ is the biomass of CEMA2 at Site 2 .

${ }^{3}$ Means represent the average of 10 transects across site with standard deviations are provided below means in table.

by about 1.8 and $0.8 \%$ at Sites 1 and 2 , respectively.

Predicted post-treatment indigenous forb cover was positively related to pretreatment indigenous forb cover (Table 2). For each $1 \%$ increase in forb cover prior to treatment, forb cover after treatment increased by $53 \%$ at both sites. At Site 2, the effect of transect was negatively associated with forb cover.

In the model predicting species richness, post-treatment species richness was positively associated with pre-treatment species richness (Table 2). Specifically, for each $1 \%$ increase in species richness, species richness increased by about $58 \%$ two years after treatment.

Predicted species diversity was negatively associated with forb cover and the spotted knapweed quadratic component, but positively related to species richness and spotted knapweed cover alone (Table 2). Specifically, each $1 \%$ increase in pre-treatment forb cover was associated with a decrease in species diversity by 0.041 Shannon-Weaver's diversity index units. For $1 \%$ unit increase in species richness, species diversity increased by 0.13 Shannon-Weaver's diversity index units. For each $1 \%$ increase in adult spotted knapweed cover, diversity increased by 0.007 Shannon-Weaver's diversity index units. For each $1 \%$ increase in the spotted knapweed quadratic component, diversity decreased by 0.00008 diversity index units.

\section{Biomass}

Indigenous perennial grass biomass prior to treatment was positively related to post-treatment forb cover and both positively and negatively related to spotted knapweed (Table 3). For each 1 unit increase in forb biomass, indigenous perennial grass biomass increased by $2.7 \mathrm{~g}$ $\mathrm{m}^{-2}$. Each 1 unit increase in spotted knapweed biomass was associated with a predicted $0.07 \mathrm{~g} \mathrm{~m}^{-2}$ decrease in indigenous perennial grass biomass at Site 1. At Site 2 , for each 1 unit increase in spotted knapweed biomass, indigenous perennial grass biomass increased by $0.40 \mathrm{~g} \mathrm{~m}^{-2}$. Each 1 unit increase in the spotted knapweed biomass by spotted knapweed interaction was associated with a predicted $0.0007 \mathrm{~g} \mathrm{~m}^{-2}$ increase in indigenous perennial grass biomass at Site 1 and a $0.004 \mathrm{~g} \mathrm{~m}^{-2}$ decrease at Site 2.

Predicted Idaho fescue biomass was positively related to indigenous perennial grass biomass from year one (Table 3 ).
For each 1 unit increase in indigenous perennial grass biomass, Idaho fescue biomass increased by $5.4 \mathrm{~g} \mathrm{~m}^{-2}$.

Each 1 unit increase in pre-treatment forb biomass was associated with a predicted $5.0 \mathrm{~g} \mathrm{~m}^{-2}$ decrease in post-treatment forb biomass (Table 3). Each 1 unit increase in species richness based on biomass was associated with an increase in forb biomass by $4.0 \mathrm{~g} \mathrm{~m}^{-2}$ at both sites. Forb biomass was negatively related to spotted knapweed biomass $\left(-0.18 \mathrm{~g} \mathrm{~m}^{-2}\right)$ at Site 1 and positively related to spotted knapweed biomass $\left(0.02 \mathrm{~g} \mathrm{~m}^{-2}\right)$ at Site 2 . Effect of transect was negatively associated with forb biomass.

Predicted species richness based on biomass was negatively related to spotted knapweed biomass (Table 3). Specifically, each 1 unit increase in spotted knapweed biomass was associated with a decrease in species richness by $0.26 \mathrm{~g} \mathrm{~m}^{-2}$ and $0.12 \mathrm{~g}$ $\mathrm{m}^{-2}$ at Sites 1 and 2, respectively.

Post-treatment species diversity was positively associated with perennial grass biomass and the spotted knapweed biomass alone, but negatively related to the spotted knapweed quadratic component (Table 3). Each 1 unit increase in indigenous perennial grass biomass was associated with an 
Table 4. Regression models predicting post-treatment non-indigenous species based on density (plants $\mathrm{m}^{-2}$ ) cover, and biomass $\left(\mathrm{g} \mathrm{m}^{-2}\right)$ variables. Empty cells represent non-significant regressor variables.

\begin{tabular}{llcccccc}
\hline \hline Site & $\begin{array}{l}\text { Predicted } \\
\text { variables } \\
\text { (Brome spp.) }\end{array}$ & Intercept & $\begin{array}{c}\text { Regressor } \\
\text { Brome }^{1} \\
\left(0 \text { to } 1,950^{2}\right. \\
(0 \text { to } 12) \\
(0 \text { to } 78)\end{array}$ & $\begin{array}{c}\text { variables } \\
(0 \text { to 38,025) } \\
(0 \text { to } 144) \\
(0 \text { to 608) }\end{array}$ & $\begin{array}{c}\text { Spotted } \\
\text { knapweed } \\
(0 \text { to } 1,170) \\
(1 \text { to } 100) \\
(0 \text { to } 1,280)\end{array}$ & $\begin{array}{c}\text { Spotted } \\
\text { knapweed } \\
(0 \text { to 313,290) } \\
(0 \text { to 10,000) } \\
(0 \text { to 163,840) }\end{array}$ & $\mathrm{R}^{2}$ \\
\hline 1 & Density & -633 & 10.6 & -0.006 & 3.9 & & 0.30 \\
2 & Density & -220 & 1.1 & 0.00 & 1.4 & & 0.31 \\
1 & Cover & -0.40 & 1.41 & -0.11 & 0.00 & & 0.13 \\
2 & Cover & -0.11 & 0.00 & 0.00 & 0.008 & & 0.10 \\
1 & Biomass & 43.0 & 0.05 & & 0.00 & & 0.15 \\
2 & Biomass & 181 & 0.00 & & -2.0 & $2.5 \times 10^{-5}$ & 0.62 \\
\hline
\end{tabular}

${ }^{1}$ Represents a pre-treatment parameter based on density, cover, and biomass to predict post-treatment Brome density, cover, and biomass, respectively.

${ }_{2}^{2}$ Possible range of values for each parameter based on density, cover, and biomass on a $\mathrm{m}^{-2}$ basis, respectively.

${ }^{3} \mathrm{~A}$ a model predicting pre-treatment brome density based on density of Brome, Brome ${ }^{2}$, and CEMA, prior to treatment includes:

Site 1; $y=633\left(B_{0}\right)+10.6\left(B_{1}\right)-0.006\left(B_{2}\right)+3.9\left(B_{3}\right)_{2}$, where $B_{0}$ is the intercept $B_{1}$ is the biomass of pre-treatment Brome, $\mathrm{B}_{2}$ is the biomass of pre-treatment Brome ${ }^{2}$, and $\mathrm{B}_{3}$ is the biomass of CEMA at Site 1;

Site $2 ; y=-220\left(B_{0}\right)+1.1\left(B_{1}\right)+1.4\left(B_{2}\right)$, where $B_{0}$ is the intercept $B_{1}$ is the biomass of pre-treatment Brome, and $\mathrm{B}_{2}$ is the biomass of CEMA at Site 2 .

increase in species diversity by 2.2 Shannon-Weaver's diversity index units. For each 1 unit increase in spotted knapweed biomass, species diversity increased by 0.11 and 0.24 Shannon-Weaver's diversity index units at Sites 1 and 2, respectively. The spotted knapweed quadratic component was related to a decrease of 0.0015 Shannon-Weaver's diversity index units. Indigenous species diversity was negatively related to transect.

\section{Brome species}

Density. Regression models were generated to describe density of post-treatment brome species based on pre-treatment brome species (Table 4). For each 1 unit increase in pre-treatment brome density, post-treatment brome increased by 10.6 tillers $\mathrm{m}^{-2}$ at Site 1 . At Site 2, each 1 unit increase in pre-treatment brome was associated with a 1.1 tillers $\mathrm{m}^{-2}$ increase in post-treatment brome. For each 1 unit increase in the brome quadratic component, post-treatment brome decreased by
0.006 tillers $\mathrm{m}^{-2}$ at Site 1 . Each 1 unit increase in spotted knapweed was associated with a predicted 3.9 tillers $\mathrm{m}^{-2}$ increase in brome at Site 1. At Site 2, each 1 unit increase in spotted knapweed was associated with a 1.4 tillers $\mathrm{m}^{-2}$ increase in brome.

Cover. For each $1 \%$ increase in pretreatment brome cover, predicted posttreatment brome cover increased by $141 \%$ at Site 1 (Table 4). For each $1 \%$ increase in the brome quadratic component, posttreatment brome decreased by $11 \%$ at Site 1. At Site 2 , each $1 \%$ increase in spotted knapweed cover was associated with a $0.8 \%$ increase in brome.

Biomass. For each 1 unit increase in pre-treatment brome biomass, post-treatment brome biomass increased by $0.05 \mathrm{~g}$ $\mathrm{m}^{-2}$ at Site 1 (Table 4). At Site 2, for each 1 unit increase in spotted knapweed, posttreatment brome decreased by $2.0 \mathrm{~g} \mathrm{~m}-2$. Each 1 unit increase in the spotted knapweed quadratic component was associated with a $2.5 \times 10-5 \mathrm{~g} \mathrm{~m}^{-2}$ increase in brome.

\section{Predicting Biomass Using Cover}

Post-treatment perennial grass biomass was positively associated with pre-treatment indigenous perennial grass cover alone, but negatively associated to the indigenous perennial grass quadratic component (Table 5). For each 1 unit increase in pre-treatment indigenous perennial grass cover, predicted post-treatment perennial grass biomass increased by $\mathbf{5 7 . 2}$ $\mathrm{g} \mathrm{m}^{-2}$ at both sites. For each 1 unit increase in the pre-treatment perennial

Table 5. Regression models predicting post-treatment biomass $\left(\mathrm{g} \mathrm{m}^{-2}\right)$ indigenous species based on pre-treatment cover of regressor variables. Empty cells represent non-significant regressor variables.

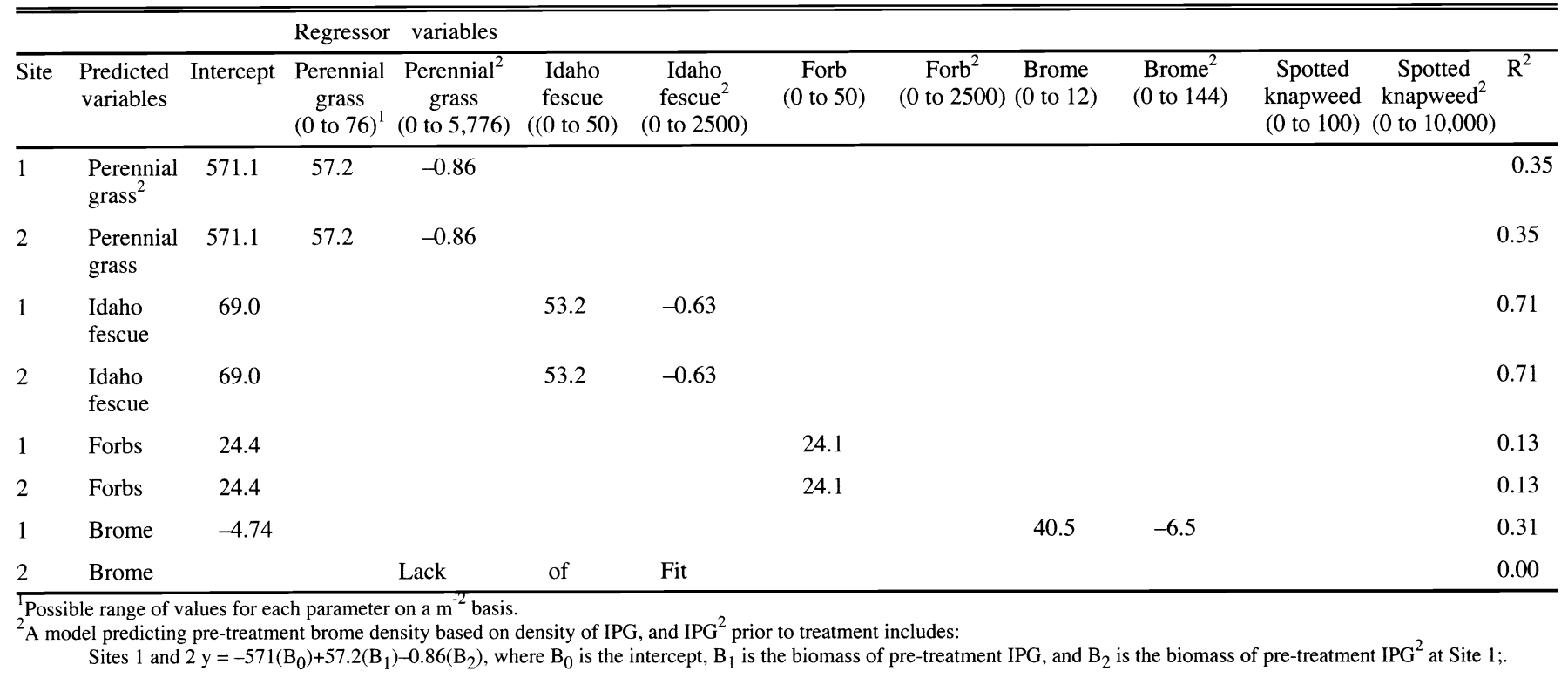


grass quadratic component based on cover, post-treatment perennial grass biomass decreased by $0.86 \mathrm{~g} \mathrm{~m}^{-2}$ at both sites.

Predicted post-treatment Idaho fescue biomass was positively associated with pre-treatment Idaho fescue cover alone, but negatively associated to the Idaho fescue quadratic component (Table 5). At both sites, each 1 unit increase in pre-treatment Idaho fescue cover was associated with a $53.2 \mathrm{~g} \mathrm{~m}^{-2}$ increase in post-treatment Idaho fescue biomass. For each 1 unit increase in the Idaho fescue quadratic component based on cover, post-treatment Idaho fescue biomass decreased by $0.63 \mathrm{~g} \mathrm{~m}^{-2}$.

Forb biomass after treatment was positively related to forb cover prior to treatment (Table 5). Each 1 unit increase in pre-treatment forb cover was associated with a $24.1 \mathrm{~g} \mathrm{~m}^{-2}$ increase in post-treatment forb biomass at both sites.

For each 1 unit increase in pre-treatment brome cover, post-treatment brome biomass increased by $40.5 \mathrm{~g} \mathrm{~m}^{-2}$ at Site1 (Table 5). For each 1 unit increase in the pre-treatment brome quadratic component based on cover, post-treatment brome biomass decreased by $6.5 \mathrm{~g} \mathrm{~m}^{-2}$. Regression analysis showed lack of fit when predicting brome production from brome cover at Site 2.

\section{Biomass Optimization Model}

Pre-treatment spotted knapweed cover was used as the regressor variable to predict pre- and post- treatment indigenous perennial grass biomass (Fig. 1). At 0 spotted knapweed cover, predicted pretreatment grass biomass was about 2,250 $\mathrm{kg} \mathrm{ha}^{-1}$ and post-treatment grass biomass was about $1,400 \mathrm{~kg} \mathrm{ha}^{-1}$. Pre-treatment grass biomass decreased rapidly as pretreatment spotted knapweed cover increased to about $50 \%$. At that point, predicted grass biomass was about $800 \mathrm{~kg} \mathrm{ha}^{-1}$. After that point, predicted grass biomass declined more slowly as spotted knapweed cover increased. The regression model predicted that areas with $95 \%$ pre-treatment spotted knapweed cover would produce $200 \mathrm{~kg} \mathrm{ha}^{-1}$ indigenous perennial grass prior to treatment. Post-treatment grass biomass decreased linearly. Predicted post-treatment grass biomass was about $500 \mathrm{~kg} \mathrm{ha}^{-1}$ at maximum spotted knapweed cover (95\%).

\section{Discussion}

\section{Predicting Indigenous Species}

Weed managers are searching for useful models on which to base their manage-

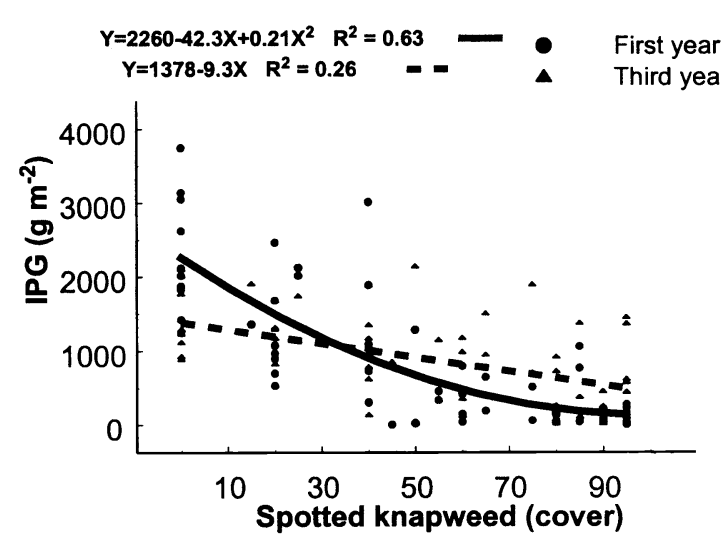

Fig. 1. Models comparing predicted post-treatment grass biomass with predicted pretreatment grass biomass based on pretreatment spotted knapweed cover.

ment decisions (Archer 1989, Laycock 1991, Schlatterer 1989). In agroecosystems, predictive models have been used to assess economic thresholds to better manage a wide range of important crops. For example, Maxwell et al. (1994) developed bioeconomic models to optimize control strategies of wild oats (Avena fatua L.) in barley production. Knezevic et al. (1994) determined redroot pigweed (Amaranthus retroflexus L.) did not reduce corn production when weed emergence occurred after the corn's 7-leaf stage. However, the use of predictive models to optimize rangeland weed management has been limited. Peat and Bowes (1994) predicted that at biomass above $290 \mathrm{~kg} \mathrm{ha}^{-1}$ of fringed sagebrush (Artemisia frigida Willd.), it becomes economically viable to control this plant using picloram. Keane (1987) developed successional pathway models to predict plant coverage based on treatment and pre-disturbance plant composition.

This study indicated it may be feasible to use pre-management plant community data to predict post-management plant community response for spotted knapweed-infested rangeland using picloram. The best predictive models for assessing post-management indigenous perennial grass, Idaho fescue, and species richness were based on density. The best models predicting post-management forbs and species diversity were based on cover and biomass, respectively. In 4 out of the 5 models, for a given post-management parameter, an important predictor in the model was its pre-management regressor variable. For example, pre-management indigenous grass density was the best predictor of post-management grass density. Additionally, pre-management spotted knapweed was a relatively unimportant predictor in most models. Incorporating environmental factors other than plant community composition into models may enhance their predictive abilities. Although this study was conducted using picloram to control spotted knapweed, other management strategies and/or other weeds could be tested in a similar fashion to predict post-management plant community response.

\section{Species Richness and Species \\ Diversity}

The model predicting species diversity based on density indicated an increase in species diversity 2 years after management. However, the species presence data along transect indicated a decrease in 14 out 30 post-management indigenous forb and grass species. Five out of 30 species (16\%) were no longer present following the picloram treatment. Four of these species were indigenous forbs. Rice et al. (1997) detected transitory declines in both species richness and diversity in response to picloram. However, this relationship may be an artifact of using ShannonWeaver's diversity index which sums the proportion of individuals present and provides an "average diversity" (Pielou 1966). Presumably an increase in postmanagement grass presence (e.g., western wheatgrass, Idaho fescue, needle-andthread, etc.) may account for this simultaneous gain in species diversity and loss of species richness (number of species) postmanagement. It is also important to note that different measurements of diversity would likely yield different predictive models.

\section{Biomass Optimization Model}

Many land management programs are aimed at maximizing grass production. These weed management programs must 
use our understanding of the change in grass biomass as a response to management. We attempted to use easily collected pre-treatment data (i.e., spotted knapweed cover) to predict pre- and post-treatment grass biomass. To identify the relative difference in biomass production between years, we compared difference between the predicted pre-treatment and post-treatment biomass. The integration of these models indicated that there would be a decrease in post-treatment grass biomass at spotted knapweed cover below $35 \%$. We suspect that at low spotted knapweed cover, interference between spotted knapweed and indigenous grass was low (Velagala 1996). Therefore, spotted knapweed removal did not result in an increase in grass biomass. We speculate that the decrease in grass biomass was associated with other environmental factors, such as weather. Above $35 \%$ spotted knapweed cover, regressions predicted greater posttreatment grass biomass than the pre-treatment biomass. In this case, spotted knapweed may have influenced grass production, and its removal may have favored grasses. In either case, including other environmental factors in the models should improve our ability to predict post-management outcomes based on pre-management conditions. Furthermore, we believe it may be possible to identify the cumulative predictive biomass gain (after treatment) by developing a biomass optimization model for each year of herbicide control. Once the change in biomass is predicted and the predictions verified, economic analysis based on the value of the biomass change may be possible using this method prior to imposing weed management.

\section{Literature Cited}

Archer, S. 1989. Have southern Texas savannas been converted to woodlands in recent history? Amer. Nat. 134:545-561.

Belcher, J. W. and S. D. Wilson. 1989. Leafy spurge and the species composition of a mixed grass prairie. J. Range Manage. 42:172-175.

Brotherson, J. D. and D. Field. 1987. Tamarix: impacts of a successful weed. Rangelands 9:110-112.

Bucher, R. F. 1984. The potential cost of spotted knapweed to Montana range users. Coop. Ext. Serv. Bull. 1316. Montana State Univ., Bozeman, Mont. $18 \mathrm{p}$.

Griffith, D. and J. R. Lacey. 1991. Economic evaluation of spotted knapweed (Centaurea maculosa) control using picloram. J. Range Manage. 44:43-47.
Keane, R. E. 1987. Classification and prediction of successional plant communities using a pathway model. pp. 56-62 In: E.E. Ferguson, P. Morgan, and F.D. Johnson (Eds) Symposium on Land Classifications Based on Vegetation: applications for resource management. USDA-FS Gen. Tech. Rep. Int-257. Intermountain Forestry and Range Exp. Sta. Ogden, Ut..

Kedzie-Webb, S. A. 1999. Relationships between spotted knapweed and indigenous plant assemblages. M.S. Thesis. Montana State Univ., Bozeman, Mont.

Knezevic, S. A., S. F. Weise, and C. J. Swanton. 1994. Interference of redroot pigweed (Amaranthus retroflexus) in corn (Zea mays). Weed Sci. 42:568-573.

Lacey, J. R., C. B. Marlow, and J. R. Lane. 1989. Influence of spotted knapweed (Centaurea maculosa) on surface runoff and sediment yield. Weed Technol. 3:627-631.

Laycock, W. A. 1991. Stable states and thresholds of range condition on North American rangelands: A viewpoint. J. Range Manage. 44:427-432.

Mack, R. N. 1981. Invasion of Bromus tectorum L. into western North America: An ecological chronical. Agroecosystems 7:145-165.

Maxwell, B. D., R. Stougaard, and E. Davis. 1994. Bioeconomic model for optimizing wild oat management in barley. Proc. West. Soc. Weed Sci. 47:74-76.

Mueggler, W. F. and W. L. Stewart. 1980. Grassland and shrubland habitat types of Western Montana. Intermountain Forest and Range Experiment Station. Ogden, Utah: USDA Forest Serv.

Neter, J., W. Wasserman, and M. H. Kutner. 1985. Applied Linear Statistical Models. 2nd ed. Richard D. Irwin, Inc. Homewood, Ill.

Page, A. L. and A. Klute. 1982. Methods of soils analysis: Part 2. Agron. 9:228-262.

Peat, C. H. and G. G. Bowes. 1994. Management of fringed sagebrush (Artemisia frigida) in Saskatchewan. Weed Technol. 8:553-558.

Pielou, E. C. 1966. The measurement of diversity in different types of biological collections. J. Theoret. Biol. 13:131-144.

Randall, J. M. 1996. Weed control for the preservation of biological diversity. Weed Technol. 10:370-383.

Rice, P. M., J. C. Toney, D. J. Bedunah, and C. E. Carlson. 1997. Plant community diversity and growth responses to herbicide applications for control of Centaurea maculosa. J. Appl. Ecol. 34:1397-1412.

SAS Institute Inc. 1990. SAS/STAT User's Guide. Ver 6. 4th ed. Vol. 2. Cary, N.C.

Schlatterer, E. F. 1989. Toward a user-friendly ecosystem: myth or mirth? pp. 223-227 In D. E. Ferguson, P. Morgan, and F. D. Johnson, (eds). Proc. Land classification based on vegetation: applications for resource management. USDA-FS Gen. Tech. Rep. INT-257. Intermountain Forestry and Range Exp. Sta., Ogden, Utah.
Schreiber, M. M. 1982. Modeling the biology of weeds for integrated weed management. Weed Sci. 30:13-16.

Shannon, C. E. and W. Weaver. 1949. The mathematical theory of communication. University of Illinois Press, Urbana, Ill.

Spoon, C. W., H. R. Bowles, and A. Kulla. 1983. Noxious weeds on the Lolo National Forest. A Situation Analysis Staff Paper. Missoula, Mont.: USDA Forest Service.

Thompson, M. J. 1996. Winter foraging response of elk to spotted knapweed removal. Northwest Sci. 70:10-19.

Tyser, R. W. and C. H. Key. 1988. Spotted knapweed in natural area fescue grasslands: An ecological assessment. Northwest Sci. 62:151-159.

Velagala, R. P. 1996. Using seed rate and plant densities to enhance intermediate wheatgrass establishment in spotted knapweed dominated rangeland. M.S. Thesis. Montana State University, Bozeman, Mont.. $66 \mathrm{p}$.

Vitousek, P. M. 1986. Biological invasions and ecosystem properties: Can species make a difference? In: H. A. Mooney and J. A. Drake, (eds). Ecology of Biological Invasions of North America and Hawaii. Springer-Verlag, New York, N.Y.

Vitousek P. M. and D. U. Hooper. 1993. Biological diversity and terrestrial ecosystem biogeochemistry. In: Ecological Studies 99: Biodiversity and Ecosystem Function. Springer-Verlag, New York, N.Y.

Whisenant, S. G. 1990. Changing fire frequencies on Idaho's Snake River Plains: Ecological and management implications. In E. D. McArthur, E. V. Romney, S. D. Smith, and P. T. Tueller, (eds). Symposium on cheatgrass invasion, shrub die-off, and other aspects of shrub biology and management. USDA Forest Service Intermountain Res. Stn. Gen. Tech. Rep. INT-276. USDA FS, Las Vegas, Nev. 